\title{
Path dependence and the stabilization of strategic premises: how the funeral industry buries itself
}

\author{
Matthias Wenzel ${ }^{1}$
}

Received: 10 February 2014/Accepted: 13 July 2015/Published online: 30 July 2015

(C) The Author(s) 2015. This article is published with open access at Springerlink.com

\begin{abstract}
Several studies have shown that path-dependent organizations may pathologically reproduce their paths even in times of crisis. The unchallenged retention of underlying strategic premises seems to play a key role in this selfdestructive process. Whereas the previous literature largely assumes that organizational crises provide sufficient impetus for updating strategic premises, recent empirical studies have highlighted that path-dependent organizations may find this highly difficult. In the present study, I explore how path-dependent organizations stabilize strategic premises even in times of crisis. Drawing on a case study of the funeral industry, I theoretically distill four mechanisms that stabilize strategic premises in path-dependent organizations despite the fierce pressures of organizational crises. While these mechanisms constitute either reflexive modes of processing feedback or generative modes of producing market outcomes, they all inhibit a disconfirmation and, thus, an update of strategic premises. Furthermore, the study presents indicative evidence of how this unchallenged retention of strategic premises leads to the pathological reproduction of the path.
\end{abstract}

Keywords Path dependence · Lock-in - Strategic premises · Stability · Funeral industry

JEL Classification $\mathrm{L} 14 \cdot \mathrm{L} 89 \cdot \mathrm{M} 10$

Matthias Wenzel

mwenzel@europa-uni.de

1 Management and Organization, European University Viadrina, Große Scharrnstraße 59, 15230

Frankfurt (Oder), Germany 


\section{Introduction}

The concept of path dependence has recently received increased attention in management research (e.g., Gruber 2010; Hutzschenreuter et al. 2007; Maielli 2015; Sydow et al. 2009; Vergne and Durand 2010). Path dependence refers to a successdriven process that may lead organizations into a state of persistence in which they continuously reproduce a strategic pattern (Sydow et al. 2009; Vergne and Durand 2010). While previous literature has traditionally focused on exploring resourcebased and routine-based reasons for such persistence, recent works bring the underlying strategic premises of paths into focus to induce a better understanding of this phenomenon (Gilbert 2005; Koch 2011; Miller and Chen 1994; Rothmann 2013; Tripsas 2009). Strategic premises tightly narrow the scope of action for the selection of strategic alternatives to the extent that paths seem to be reproduced as long as the underlying strategic premises remain unchanged (Rothmann and Koch 2014; Tripsas and Gavetti 2000). With that, unchanged strategic premises seem to constitute the main-if not the most important-driver of path reproduction (Tripsas 2009).

Prior literature predominantly suggests that path-dependent organizations update their strategic premises at the latest when they are struck by crises, i.e., environmental changes that render path reproduction inefficient and threaten organizational survival (e.g., Dobusch and Kapeller 2013; Pearson and Clair 1998; Tushman and Anderson 1986). The negative feedback that organizational crises generate is deemed sufficient to challenge the status quo and begin a process of reflection on, and revision of, strategic premises (Schreyögg and Kliesch-Eberl 2007). Along with the adjustment of strategic premises, such shocks would rebroaden the scope for off-path activities (Koch 2011; Sydow et al. 2009; Vergne and Durand 2010).

Paradoxically, prior research has shown that path-dependent organizations may not change their underlying strategic premises despite severe crises. Instead, these organizations may leave their strategic premises uncontested even in times of crisis and pathologically reproduce their established path instead of conducting strategic change (e.g., Gilbert 2005; Rothmann and Koch 2014; Sull 1999). The uncontested retention of strategic premises even in times of crisis indicates the existence of mechanisms that stabilize strategic premises (e.g., Geiger and Antonacopoulou 2009; McKinley et al. 2014; Schreyögg and Kliesch-Eberl 2007). These mechanisms have remained unexplored so far (Bingham and Kahl 2014; Dobusch and Schüßler 2013; Eggers and Kaplan 2013; O’Reilly and Tushman 2013; Tripsas 2009).

The scant attention devoted to mechanisms that stabilize strategic premises is surprising, given that previous literature emphasizes the retention of strategic premises as an important reason for path reproduction in times of crisis (Rothmann and Koch 2014; Tripsas 2009; Tripsas and Gavetti 2000). Thus, although prior research has made considerable progress in gaining a better understanding of the pathological reproduction of paths, exploring the mechanisms that inhibit the update of strategic premises may provide valuable complementary insights into this 
phenomenon (Hutzschenreuter and Kleindienst 2013; Rothmann and Koch 2014; Sydow et al. 2012a). Given that only a minor portion of path-dependent organizations seem to be able to leave, and most organizations seem to pathologically reproduce, their path despite threatening crises, it seems that further research on the pathological reproduction of paths is warranted (McKinley et al. 2014). Therefore, the present study aims to increase our knowledge on this phenomenon by exploring how path-dependent organizations stabilize strategic premises even in times of crisis.

I address this issue in a case study of the funeral industry in Berlin, Germany. After decades of success in which a predominant strategic pattern had emerged, the focal industry was hit by a major downturn at the end of the 1990s when so-called "discount funeral homes" exerted pressure on prices with supra-regional online offers. Consistent with their strategic premises, the incumbents reacted to this crisis with efforts to restore the efficiency of the established strategic pattern. These responses did not alleviate the crisis, and yet, the underlying strategic premises remained uncontested. In analyzing these developments, I identify four mechanisms that stabilize strategic premises in path-dependent organizations even in times of crisis. These mechanisms relate to the reflexive processing of market feedback and the generative production of market outcomes that reinforce strategic premises. The presented findings indicate that the stabilized strategic premises leave little scope for deviations from the established strategic pattern and lead to the pathological reproduction of the path.

The results presented in this paper offer several extensions of the literature on path dependence and related research. First, this paper complements prior works on path reproduction with tentative insights into the retention of strategic premises. Due to the important role of premise stability for path reproduction, the explored mechanisms that stabilize strategic premises even in times of crisis and, therefore, obstruct strategic change shed further light on the pathological reproduction of paths and incumbents' challenges to conduct strategic change (Rothmann and Koch 2014; Tripsas 2009). Second, this paper offers a more nuanced understanding of the uncontested retention of strategic premises even in times of crisis. By unbundling mechanisms of premise stabilization, this paper suggests that challenging strategic premises does not result from the reception of negative feedback per se but depends on how organizations process incoming feedback (Koch et al. 2009). The explored mechanisms of reflexive feedback processing provide indicative evidence of how organizations avoid a disconfirmation of their strategic premises in response to negative feedback. Third, this paper extends beyond the discussion of feedback processing by opening the theoretical perspective for the endogenous creation of market outcomes. While previous literature has predominantly focused on "myopic" feedback processing in which strategic premises "self-perpetuate", the present findings indicate that organizations may also actively engage in market activities to produce market outcomes that do not disconfirm strategic premises (e.g., Gilbert 2006; Koch 2008; Miller 1994). With that, the paper also adds to the debate on agency by suggesting that path-dependent organizations may use their agency to pathologically extend their path (e.g., Duschek 2010; Garud et al. 2010; Sydow et al. 2012a). 
The remainder of the paper is organized as follows: In Sect. 2, I review previous literature on path dependence and related research to clarify the predominant understanding of the concept and the role of strategic premises that this literature highlights. In Sect. 3, I describe the applied methodology and in Sect. 4, I present the findings of my empirical analysis of the case of incumbent funeral homes in Berlin that led to the identification of mechanisms that stabilize strategic premises even in times of crisis. In Sect. 5, I discuss theoretical contributions and implications of these findings and provide directions for future research.

\section{Path dependence and strategic premises}

Since its inception by David (1985) and Arthur (1989), the concept of path dependence has found application in many fields of research, such as economics, sociology, political science, and information systems (Mahoney 2000; Pierson 2000; Sambamurthy et al. 2003; Shapiro and Varian 1999). Management scholars have also extensively referred to path dependence to explain a variety of strategic phenomena (Vergne and Durand 2011). In line with debates on further conceptual advancements of path dependence in managerial contexts, recent contributions to the management literature have disseminated a more comprehensive understanding of the concept (Garud et al. 2010; Sydow et al. 2009; Vergne and Durand 2010). Based on these works, management scholars have come to understand path dependence predominantly as a process that explains the reduction of managerial scope over time (Dobusch and Kapeller 2013). Path dependence provides powerful answers to both how and why strategic patterns-the selected combination of organizational routines and resources-are reproduced (Koch 2008, 2011; Vergne and Durand 2011). Although certain conceptual details remain subject to further debate, Dobusch and Kapeller (2013) identified a theoretical consolidation of path

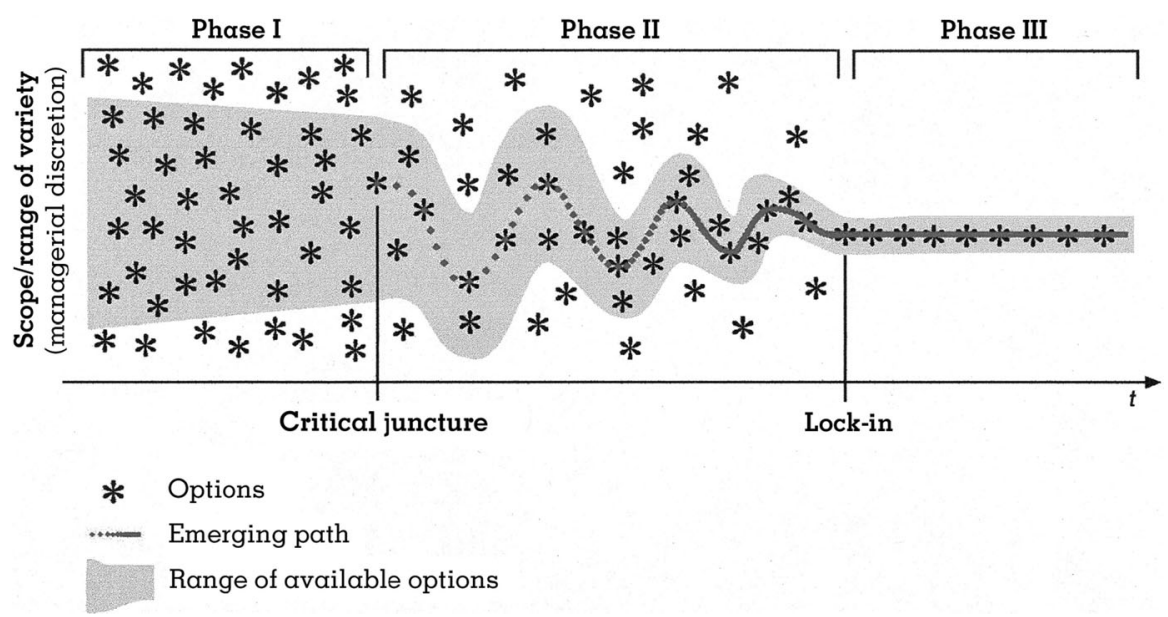

Fig. 1 The constitution of a path (Sydow et al. 2009: 692) 
dependence based on a common understanding that analytically distinguishes between three phases: contingency, self-reinforcement, and lock-in (see also Fig. 1).

At the beginning of path-dependent processes, the range of variety is considerably broad. Although strategic choice is hardly predictable based on initial conditions or prior events, the strategic decisions made in this phase affect the outcome of the process (David 1985).

A seemingly small and oftentimes random choice of an option may unwittingly trigger self-reinforcing mechanisms, i.e., processes that generate positive feedback on the selection of a specific strategic option while gradually rendering strategic alternatives unattractive (Arthur 1989). Prominent examples include coordination effects, i.e., "covering utility resulting from others following the same path" (Dobusch and Schüßler 2013: 623), and adaptive expectation effects, i.e., the development of expectations "in response to the expectations of others" (Sydow et al. 2009: 700). These mechanisms may unfold their self-reinforcing effects even beyond organizational boundaries (Dobusch and Schüßler 2013; Maielli 2015; Schmidt and Braun forthcoming).

When organizations eventually reproduce one prevailing strategic pattern, they have entered a state of lock-in, a situation in which they have only a limited corridor of options available (Sydow et al. 2009; Vergne and Durand 2010). Although lockins are an organizational phenomenon, they do not seem to be idiosyncratic to single organizations in all cases. Particularly in mature industries, the strategic activities of incumbents tend to converge to the extent that several, or even all, organizations within an industry may be trapped in the same path (Benner and Tripsas 2012; Kunow et al. 2013; Lampel and Shamsie 2003; Rothmann and Koch 2014; Vergne and Durand 2011).

Although lock-ins may eventually become inefficient, they may not be problematic from the outset. The positive feedback that produces a predominant strategic pattern may lead affected organizations to a strategic fit with the environment (Vergne and Durand 2011). Therefore, path-dependent organizations may reproduce a strategic pattern successfully for long periods of time (Rothmann and Koch 2014). However, a successful strategic pattern may turn into a burden when the environment changes (Leonard-Barton 1992). Because the corridor of options is sacrificed for improving the fit of a strategic pattern to the given environmental conditions, affected organizations do not perceive any scope of action to adapt their strategic pattern to environmental changes (Sydow et al. 2009). Therefore, a formerly successful strategic pattern may eventually become misaligned with the new environmental conditions and can hardly be changed (Rothmann and Koch 2014; Vergne and Durand 2011).

While path dependence theory illuminates how affected organizations lose their scope of action over time, the broader management literature on incumbents' rigidities sheds further light on the challenges of path-dependent organizations to change their strategic patterns in response to changes in the environment (e.g., Christensen and Bower 1996; Kaplan 2008; Miller 1993; Tripsas 1997; Tushman and Anderson 1986). In particular, this stream of literature has predominantly explored resource-based and routine-based reasons for the stability of strategic patterns (Eggers and Kaplan 2013; Gilbert 2005; Hill and Rothaermel 2003). 
Resource-based reasons relate to organizations' unwillingness to change resource investments because of tendencies to exploit prior investments in the optimality of existing strategic patterns, increased opportunity costs, and risk avoidance (Christensen and Bower 1996; March 1991; Miller and Chen 1994). Routine-based reasons refer to organizations' inability to adapt the processes that use resources, which results in an inappropriate use of acquired resources under new environmental conditions and an insufficient exploration of strategic alternatives (Burgelman 2002; Danneels 2011; Gilbert and Bower 2002). Resource-based and routinebased reasons for the stability of strategic patterns have emerged almost independently. However, given the complexity of path-dependent processes, recent contributions to this stream of literature emphasize that resource-based and routinebased reasons for the stability of strategic patterns appear jointly in most cases of path dependence (Eggers and Kaplan 2013; Gilbert 2005; Hill and Rothaermel 2003; Kaplan and Henderson 2005; Rothmann and Koch 2014).

Recent contributions to the literature on incumbents' rigidities and path dependence emphasize that both resource-based and routine-based reasons for the stability of strategic patterns can largely be traced back to organizations' unchanged strategic premises (Benner and Tripsas 2012; Gilbert 2005, 2006; Koch 2011; Rothmann and Koch 2014; Tripsas and Gavetti 2000). Strategic premises are the basic assumptions on which strategic patterns are based and consist of a system's self-understanding and its perception of the environment (Albert and Whetten 1985; Porac and Thomas 1989). In mature industries, the strategic premises of market players may converge even across different institutional frameworks (Benner and Tripsas 2012; Flier et al. 2003; Huff 1982; Porac et al. 1989; Spender 1989). While strategic premises generally guide strategic choice, they may become particularly problematic in lock-ins (Tripsas 2009). Because strategic premises constitute an essential part of the organizational context in which the strategic path is engraved, they tightly constrain strategic activities in lock-ins due to constrained perceptions or normative rejections of strategic alternatives and the contraction of resource investments (Koch 2011; Miller and Chen 1994; Rothmann 2013; Sydow et al. 2009; Tripsas and Gavetti 2000). Therefore, the literature on incumbents' rigidities and path dependence regards the update of potentially obsolete strategic premises in lock-ins as a necessary pre-condition for strategic change in lock-ins (Rothmann and Koch 2014; Tripsas 2009; Tripsas and Gavetti 2000).

The literature on incumbents' rigidities and path dependence predominantly explains the persistence of obsolete strategic premises by ascribing myopia to the path-dependent organizations, i.e., the failure to recognize the need for an update of strategic premises (Eggers and Kaplan 2013; Geiger and Antonacopoulou 2009; Koch 2008). Thus, this literature strengthens the idea that path-dependent organizations filter out negative feedback that would challenge their strategic premises (Burgelman 1994; Koch 2011; Levinthal and March 1993; Rothmann 2013; Tripsas and Gavetti 2000; Tripsas 2009). In this way, strategic premises become "self-perpetuating" (Gilbert 2006: 152; Miller 1994): the affected organizations perceive their environment from the background of their strategic premises and become "blind" for feedback that would challenge their strategic premises. 
However, although path-dependent organizations may "myopically" ignore the need for an update of strategic premises for a long period of time, prior literature on incumbents' rigidities and path dependence emphasizes that these organizations hardly seem to do so when they are struck by a severe crisis (Dobusch and Kapeller 2013; Hill and Rothaermel 2003; Levinthal and March 1993; Schreyögg and Kliesch-Eberl 2007; Tushman and Anderson 1986). Organizational crises are situations that threaten the survival of the affected organizations and, therefore, challenge existing strategic premises in which the reproduced strategic pattern is embedded (Pearson and Clair 1998). Due to the strongly negative feedback that these threatening situations generate, path-dependent organizations seem to become aware of problems with underlying strategic premises, to be motivated to reflexively search for alternative strategic premises, and to replace obsolete premises with new, supposedly superior, strategic premises (Schreyögg and Kliesch-Eberl 2007). Thus, beyond the debate on the role of agency with which organizations may possibly extend or even create a new path based on the same strategic premises, there seems to be a minimal consensus that organizational crises provide sufficient impetus for updating strategic premises (Duschek 2010; Garud and Karnøe 2001; Garud et al. 2010; Meyer and Schubert 2007; Schreyögg and Kliesch-Eberl 2007; Sydow et al. 2009, 2012a).

However, some organizations in a variety of industries have been shown to be unable to update their strategic premises in times of crisis despite the strongly negative feedback they received (Eggers and Kaplan 2013; Gilbert 2005; Koch 2011; MacKay and Chia 2013; Maielli 2015; Miller and Chen 1994; Rosenbloom 2000; Rothmann and Koch 2014; Schreyögg et al. 2011; Sull 1999; Tripsas 1997, 2009; Tripsas and Gavetti 2000). For example, Rothmann and Koch (2014) presented the case of path-dependent organizations in an industry that were struck heavily by a severe crisis. In contrast to a "failure to act" (Weick 1979: 149), these organizations evoked an elevated number of strategic initiatives in response to the strongly negative feedback they received. Yet, these actions did not lead to strategic change but were aimed at restoring the efficiency of the formerly successful strategic pattern because the underlying strategic premises remained uncontested (see also Gilbert 2005; Gilbert and Bower 2002). Sull (1999) notably referred to this phenomenon as "the dynamics of standing still."

The uncontested retention of strategic premises despite the shock-inducing forces of crises indicates that, as opposed to self-reinforcing mechanisms that provide positive feedback on reproducing strategic patterns, self-destructive mechanisms that stabilize and, therefore, avert an update of strategic premises in light of disconfirming feedback must be at work (Geiger and Antonacopoulou 2009; Langley et al. 2013; McKinley et al. 2014; MacKay and Chia 2013; Schreyögg and Kliesch-Eberl 2007). Because these mechanisms seem to inhibit strategic change by leaving strategic premises uncontested, they may provide further insights into the pathological reproduction of paths (Hutzschenreuter and Kleindienst 2013; Rothmann and Koch 2014; Sydow et al. 2012a). However, despite the emphasized importance of updating strategic premises for strategic change, there is surprisingly little prior work that provides more detailed answers to the question of how pathdependent organizations retain their obsolete strategic premises even in times of 
crisis (Bingham and Kahl 2014; Dobusch and Schüßler 2013; Eggers and Kaplan 2013; O’Reilly and Tushman 2013; Tripsas 2009).

\section{Methods}

\subsection{Design and empirical setting}

To explore how path-dependent organizations stabilize strategic premises even in times of crisis, I conducted a qualitative case study with a longitudinal retrospective research design (Sydow et al. 2012b; Yin 2014). Because of the dearth of prior research on stabilizing mechanisms, a qualitative case study seemed particularly suitable to explore these mechanisms (Yin 2014). Furthermore, the complexity of both paths and strategic premises suggested qualitative methods to draw informed conclusions concerning their social dynamics (Dobusch and Kapeller 2013; Durand and Vaara 2009; Eisenhardt 1989). I chose a longitudinal retrospective design because paths, strategic premises, and the underlying mechanisms may best be observed in such a design (Dobusch and Schüßler 2013; Dutton and Dukerich 1991; Langley et al. 2013).

The case of incumbent organizations in the funeral industry in Berlin, Germany, provided a compelling empirical site in which the phenomenon of interest was particularly salient (Strauss 1987). Especially in the analyzed period from 1996 to 2010 , it constituted a "talking pig" for a rigid strategic pattern that once was successful but has since become a burden (Breuer and Daumann 2010; Siggelkow 2007). The incumbents in the funeral industry in Berlin constituted a unique case because they were the few players worldwide that were struck by a severe crisis due to the market entrance of so-called "discount funeral homes" in the 1990s (Akyel 2013; Yin 2014). The market activities of these players deviated sharply from the incumbents' established, formerly successful strategic pattern, which had dramatic consequences for its outcome (Breuer and Daumann 2010). As illustrated in Fig. 2, revenues decreased drastically in the following years and, after a brief upturn, languished at an even lower level until the end of the period of interest. Despite the

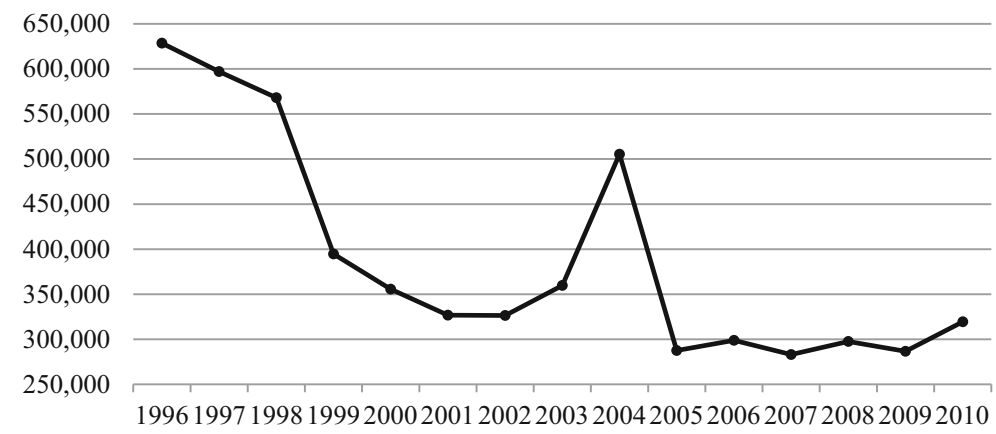

Fig. 2 Revenues per funeral home in EUR (own calculations based on data provided by Destatis) 
fierce pressures in this region and the resulting crisis of incumbent funeral homes, the organizations hardly deviated from their established strategic pattern (Breuer and Daumann 2010). This indicated that the incumbents' underlying strategic premises had remained unchallenged because of stabilizing mechanisms (Bingham and Kahl 2014; Schreyögg and Kliesch-Eberl 2007; Tripsas 2009).

In line with observations of path dependence in other mature industries, the strategic activities and underlying strategic premises of incumbent funeral homes in Berlin strongly converged, and the industry's incumbents were equally affected by

Table 1 Overview of interview data

\begin{tabular}{|c|c|c|c|}
\hline Expert & Position & Number of interviews & Length \\
\hline 1 & Funeral director, head of an industry association & 2 & $\begin{array}{l}01: 09: 05 \\
01: 25: 02\end{array}$ \\
\hline 2 & Funeral director, publicist about funeral issues ${ }^{\mathrm{a}}$ & & \\
\hline 3 & Cemetery administrator & 2 & $\begin{array}{l}01: 11: 10 \\
01: 32: 59\end{array}$ \\
\hline 4 & Funeral director, head of an industry association & 2 & $\begin{array}{l}01: 16: 12 \\
01: 40: 46\end{array}$ \\
\hline 5 & Head of an industry association & 2 & $\begin{array}{l}01: 43: 21 \\
01: 04: 35\end{array}$ \\
\hline 6 & Consultant for funeral homes & 2 & $\begin{array}{l}01: 07: 13 \\
01: 01: 16\end{array}$ \\
\hline 7 & Supplier for funeral homes & 2 & $\begin{array}{l}01: 51: 45 \\
01: 34: 41\end{array}$ \\
\hline 8 & Funeral director & 2 & $\begin{array}{l}01: 15: 37 \\
01: 48: 04\end{array}$ \\
\hline 9 & Funeral director & 2 & $\begin{array}{l}02: 10: 00^{\mathrm{b}} \\
02: 07: 00^{\mathrm{b}}\end{array}$ \\
\hline 10 & Supplier for funeral homes & $2^{\mathrm{c}}$ & $00: 56: 56$ \\
\hline 11 & Funeral director & 2 & $\begin{array}{l}00: 44: 22 \\
01: 46: 30\end{array}$ \\
\hline 12 & Funeral director, head of an industry association & 2 & $\begin{array}{l}01: 14: 04 \\
01: 57: 08\end{array}$ \\
\hline 13 & Funeral director & 2 & $\begin{array}{l}01: 08: 06 \\
02: 16: 33\end{array}$ \\
\hline 14 & Funeral director & 2 & $\begin{array}{l}01: 12: 51 \\
01: 08: 24\end{array}$ \\
\hline & & $\sum 25$ & $\sum 36: 23: 40$ \\
\hline
\end{tabular}

\footnotetext{
${ }^{a}$ I conducted the interviews with Expert 2 jointly with Expert 1

b No audio material available

c I conducted the second interview with Expert 10 jointly with Expert 7. Therefore, I reduced the indicated sum of interviews by one
} 
the market entry of discount funeral homes (Breuer and Daumann 2010; Kunow et al. 2013; Rothmann and Koch 2014; Vergne and Durand 2011). Thus, even if the organizations might have differed in peculiar aspects, these differences were too small to deviate from the same strategic path (Becker 2004; Burgelman 2010). Accordingly, variations among individual players were insufficient for cross-case comparisons (Eisenhardt 1989). This lack of variation facilitated the joint analysis of the strategic activities and the stabilization of the underlying strategic premises of the incumbent funeral homes in Berlin as a holistic single case (Klein et al. 1994; Yin 2014).

\subsection{Data collection}

To capture rich insights into the studied phenomenon and to facilitate data triangulation, I relied on multiple sources of evidence (Yin 2014). Accordingly, the data collection followed a three-stage process. First, to obtain a rich understanding of the context and to unveil the path by putting the path into perspective, I accessed secondary data on the funeral industry in Berlin for the period of interest (Eisenhardt 1989; Sydow et al. 2012b). In particular, I gathered quantitative data on the overall developments in the studied arena. Because published data on the funeral industry were highly aggregated in most cases and, therefore, provided few insights into the industry's peculiar developments in Berlin, I contacted the Federal Statistical Office of Germany (Destatis) to obtain more fine-grained data (available upon request). Furthermore, I searched for newspaper articles in relevant databases (LexisNexis, Wiso) based on keywords ("funeral industry AND Berlin," "funeral home AND Berlin," etc.). After having read all of the articles that I found, I saved the (399) relevant ones for further analysis.

Second, because patterned activities can be recalled and communicated and their underlying premises are revealed in narratives, I gathered primary data by conducting 25 interviews (Garud et al. 2010; see Table 1). The dynamics of path dependence may be beyond the control of actors within affected systems, which means that external observers are a particularly valuable source for the reconstruction of paths (Sydow et al. 2012b). Because path dependence is a phenomenon that spans multiple levels of analysis, interviewing experts appeared to be particularly promising for generating rich insights (Klein et al. 1994; Koch 2011; Sydow et al. 2012b; Vergne and Durand 2010, 2011). Therefore, I conducted semi-structured interviews with central experts on the funeral industry in Berlin (Klag and Langley 2013). The selection of interviewees did not follow guidelines for statistical sampling procedures. Instead, as required for qualitative studies, I selected interview partners based on theoretical criteria, i.e., to obtain rich insights into the phenomenon of interest, the interviewees were required to have extended knowledge of the path of the incumbent organizations in the funeral industry in Berlin, the path's underlying strategic premises, and the mechanisms that stabilize these premises (Eisenhardt 1989; Koch 2011; Langley et al. 2013). I identified these experts either through their repeated appearance as interviewed experts in newspaper articles or based on the recommendations of industry associations (Miles and Huberman 1994). To ensure trustworthiness, they were also required to 
have diverse knowledge backgrounds for triangulation purposes (Lincoln and Guba 1985). Therefore, several experts selected for this study differed with regard to their positions within the industry, e.g., consultants, suppliers, and cemetery administrators. Thus, they engaged with the focal organizations for different purposes. Because some of the experts performed industry-related meta-functions, e.g., as representatives, and simultaneously were owners of long-established incumbent funeral homes, the analysis of the data facilitated both the reconstruction of the strategic premises of the organizations in the focal industry and a rich understanding of the path-dependent dynamics involved (Sydow et al. 2012a). As noted above, the narrative reports of the interviewed funeral directors on their limited scope of strategic activities as well as the underlying strategic premises that could be reconstructed from these interviews were astonishingly similar. The triangulation of these accounts with data gathered through interviews with external observers aided in the identification of certain blind spots to analyze and better understand the path in which the incumbent funeral homes were trapped (Schreyögg and Kliesch-Eberl 2007). The interviews lasted for a total of more than $36 \mathrm{~h}$, with an average interview length of approximately $87 \mathrm{~min}$. All but two of the interviews were audiotaped and transcribed for further analysis. One interviewee refused to be audio-recorded; these interviews were recorded in writing and the content of the protocols were subsequently verified and confirmed by the interviewee (Miles and Huberman 1994). In the process of analyzing the data, I continuously contacted the experts via informal phone calls to develop and revise the emerging findings (Lincoln and Guba 1985).

Third, I acknowledged that narrative reports of strategic patterns may diverge from factual performance (Koch 2011). Thus, after a preliminary analysis of the collected data, I verified the existence of patterned strategic activities by gathering data through direct on-site observations in ten incumbent funeral homes in Berlin (Calori 2002). I relied on the principles of theoretical sampling by selecting prototypical organizations in which the phenomenon of interest could best be observed (Eisenhardt 1989). I identified these funeral homes based on the recommendations of the interviewed experts (Miles and Huberman 1994). Whereas most funeral directors allowed data collection for at most $1 \mathrm{~h}$, I was able to enter two prototypical funeral homes for two workdays each. I observed all parts of the value chain, from first contact with consumers in the funeral home to the delivery of the service at the cemetery (with subcontractors). I immediately recorded my observations through field notes and wrote extended reports at the end of each day of observation (Miles and Huberman 1994). Additionally, I conducted follow-up interviews with all experts to verify and increase the trustworthiness of my findings (Lincoln and Guba 1985).

\subsection{Data analysis}

In preparation for the data analysis, I imported all of the gathered data into the qualitative data analysis software Atlas.ti, v7.1, to construct a case study database that would increase reliability (Yin 2014). Next, I used this software to code, categorize, and analyze the gathered data. 
The analysis of gathered data proceeded in two main stages. First, I conducted a path analysis to verify whether path dependence existed in the funeral industry in Berlin at all (Sydow et al. 2009). In contrast to grounded theory approaches that start theory-building without any theoretical preferences, path analyses may draw on established frameworks to derive codes deductively (Glaser and Strauss 1967; Sydow et al. 2012b). In particular, I used Koch's $(2008,2011)$ framework for the analysis of strategic paths (see Table 2). This procedure began with a "path assumption" - the presumption that the observed rigidity follows a path-dependent pattern-and was composed of (1) the identification of at least one strategic pattern that is persistently reproduced over time; (2) the detection of at least one positive feedback loop that is related to the identified strategic pattern; (3) the recognition of a critical event in the environment that renders the pattern inefficient; (4) an examination of the ability to overcome the discovered rigidity by observing whether responses to the critical event, if existent, are not successful; and (5) the identification of the reasons for path dependence as being either resource-based (resource constraints) or of a cognitive (alternatives not recognized) or normative (alternatives recognized but still rejected) character. To obtain such fine-grained insights, this procedure permeated different levels of analysis, i.e., "strategic activities ('what a strategic system does and what it does not do'), strategic talk ("what a strategic system "says"/does not "say"), strategic reflection ("how a strategic system justifies what it does/“says"'), and strategic basic assumptions ("to what kind of strategic premises a strategic system refers')" (Koch 2011: 347; see

Table 2 Coding structure (path analysis)

\begin{tabular}{|c|c|}
\hline Coding category & Description \\
\hline \multicolumn{2}{|l|}{ The path } \\
\hline Strategic pattern & $\begin{array}{l}\text { Descriptions of patterned strategic activities that are persistently reproduced } \\
\text { over time }\end{array}$ \\
\hline $\begin{array}{l}\text { Self-reinforcing } \\
\text { mechanisms }\end{array}$ & Positive feedback loops related to the strategic pattern \\
\hline \multicolumn{2}{|c|}{ Critical environmental change and reactions to the crisis } \\
\hline Rationality shift & Critical events that render the strategic pattern inefficient \\
\hline Strategic alternatives & Alternatives to the established strategic pattern \\
\hline Reactions to crisis & Responses to the rationality shift \\
\hline Response outcome & $\begin{array}{l}\text { Success/failure of responses (indications of the ability to take alternative } \\
\text { strategic actions) }\end{array}$ \\
\hline \multicolumn{2}{|c|}{ Underlying logic of strategic activities } \\
\hline Strategic discourse & $\begin{array}{l}\text { Central topics debated in the observed industry (indications of a cognitive } \\
\text { lock-in) }\end{array}$ \\
\hline Strategic reflection & $\begin{array}{l}\text { Justification of strategic activities (indications of a normative or resource- } \\
\text { based lock-in) }\end{array}$ \\
\hline $\begin{array}{c}\text { Strategic basic } \\
\text { assumptions }\end{array}$ & Premises about the organizational self-understanding and the environment \\
\hline
\end{tabular}


also Sydow et al. 2012b). Thus, this procedure not only facilitated the necessary verification of path dependence as the specific form of observed rigidity but also enabled the reconstruction of the path's underlying strategic premises.

Second, when I was confident that I had a rich understanding of the observed path and the underlying strategic premises, I complemented the deducted set of codes with further coding categories that emerged from the data (Klag and Langley 2013). Consistent with the research question, I paid particular attention to how the reconstructed strategic premises were stabilized by coding corresponding instances with in vivo codes on the basis of terms or phrases that appeared in the data (Miles and Huberman 1994). This procedure resulted in an extensive list of 76 codes that contained considerable code overlaps. Accordingly, I merged the generated codes that were similar in both character and purpose (Van Maanen 1979). Furthermore, I checked for the completeness and consistency of the coding scheme in debriefing sessions with colleagues (Isabella 1990). I repeated this process until I could not identify any additional code overlaps. To establish coding reliability, I employed a second coder who used the developed coding schemes. Dividing the number of agreements by the number of agreements and disagreements yielded a reliability rating of .86, which indicated an acceptable level (Miles and Huberman 1994). Then, I discussed and resolved all disagreements with the second coder. For theoretical abstraction, I checked for possibilities to further categorize the generated codes by considering linkages among them (Yin 2014). This was not a linear process; instead, I iteratively moved between the developed codes and emerging patterns to develop conceptual categories (Eisenhardt 1989). The tools for constant comparison that the qualitative data analysis software contains provided considerable assistance in identifying further category nestings (see also Clark et al. 2010; Dacin et al. 2010). Based on this analytical procedure, I formed higher-order categories that facilitated an interpretation of the data at a more abstract level (Van Maanen 1979). As illustrated in Fig. 3, I theoretically distilled four mechanisms that stabilize strategic premises, the retention of which inhibits the deviation from established strategic patterns despite an ongoing crisis. During the analysis, it became clear that the mechanisms that emerged from the data could be characterized either as a reflexive mode of processing market feedback or as a generative mode of producing market

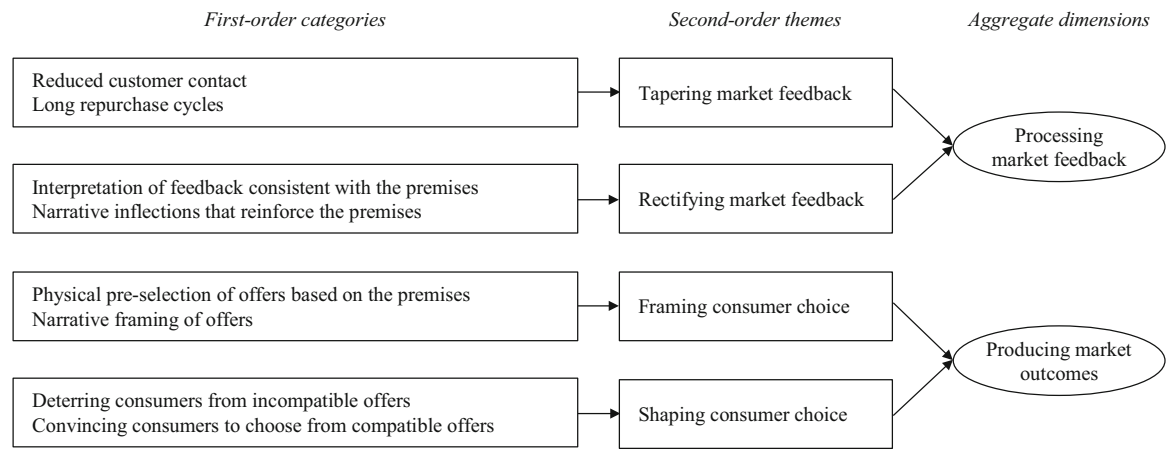

Fig. 3 Coding structure (stabilization of strategic premises) 
outcomes. Accordingly, I further assigned these mechanisms to either one of two aggregate dimensions that specify these modes.

\section{Findings}

To provide a comprehensive description of the identified mechanisms that stabilize strategic premises, I structure the case description in line with the analytical steps that were necessary to explore these mechanisms. Thus, at the outset, I describe the path in which the incumbent funeral homes in Berlin were trapped, how the organizations entered a severe crisis, and how they reacted to the crisis (Koch 2008, 2011). Then, I reconstruct the underlying strategic premises that entrenched the funeral homes' strategic activities and led to the pathological reproduction of the path. Last, I describe how the funeral homes stabilized these strategic premises despite the ongoing crisis.

\subsection{Path description, crisis, and reactions to the crisis}

Organizations operating in the funeral industry in Berlin lived through startlingly successful times particularly from the 1960s to the 1980s. This era-known as the "Golden Age" (Expert 12)—was extraordinary because success required little effort.

It just went well. They just had to be there. Quality and service did not play any role. (Expert 6)

This beneficial position may partly be explained by the provision of funeral allowances from statutory providers of health insurance that granted the bereaved greater financial scope. However, despite the low importance of the provided quality at the time, the funeral homes counted on repurchases at later times of need.

There are cycles: someone was here five years ago, ten years ago, or even longer ago. The next death happens within the family or the circle of acquaintances, and then, they come back [...], and so on. This is, of course, the best or the classical line. (Expert 1)

Due to the limitation of demand being related to death and the highly competitive market situation, retaining a regular customer base generated a steady stream of revenue that ensured the funeral homes' continued existence. Instead of counteracting the switch of customers to other market players by competing on quality or price (Porter 1980), the funeral homes relied on their "catchment area in which the people selected a funeral home in their vicinity [but] the funeral homes as such hardly differ" (Expert 8). In line with this "territorial thing" (Expert 14), a "nonaggression pact" between organizations ensured that a competitive situation within the industry would not emerge.

Among older companies [...], there is a sort of code of honor [...]. You don't go there with a pound of coffee and say, 'Here I am. Just call me.' (Expert 4) 
Thus, this non-aggression pact required organizations to decline to acquire new customers and to rely on their own established clientele. The more organizations that complied with this code, the more attractive reliance on regular customers became due to the lower risk of competitive pressures. Accordingly, the focus on regular customers was driven by "coordination effects," a self-reinforcing mechanism of path dependence (Sydow et al. 2009).

However, the neutralization of competition did not render customer satisfaction entirely irrelevant because consumers could potentially switch to competitors on their own due to dissatisfaction. Furthermore, the code may have stifled active initiatives to acquire new customers, but it could not prevent passive enlargements of the customer base through testimonials from existing customers.

We not only exist due to the [customers living] here but also due to [...] many former $[\ldots]$ customers that recommend us throughout Berlin. (Expert 4)

Thus, reputation-consumers' judgments of organizational capacities to create value (Rindova et al. 2005) — played an important role both for the retention and the enlargement of the customer base beyond the immediate catchment area. The value of reputation as a driver of repurchases only unfolds when organizations comply with consumer expectations (Mishina et al. 2012). Accordingly, strategic activities became increasingly tied to the perceived market demand and condensed to a reproduced strategic pattern. Consistent with the comparably high portion of church members among the inhabitants of Berlin during the Golden Age, traditional funerals mostly contained uniform rites consistent with Christian traditions.

Funeral services were held by reverends, such that they always followed a certain sequence of events. (Expert 8)

Thus, by constructing the service concept according to perceived consumer expectations, leveraging reputation was tightly connected to "adaptive expectation effects," another self-reinforcing mechanism of path dependence that drove the funeral homes' focus on regular customers (Sydow et al. 2009).

Although funeral services were highly complex and composed of many components, the coffin was "the invoice item that contains the largest profit margin" (Expert 1). Pricing one component considerably higher than its acquisition price and adding most of the other items of the service for free obscured the cost structure of the service. Furthermore, it was "an absolute taboo to quote prices"

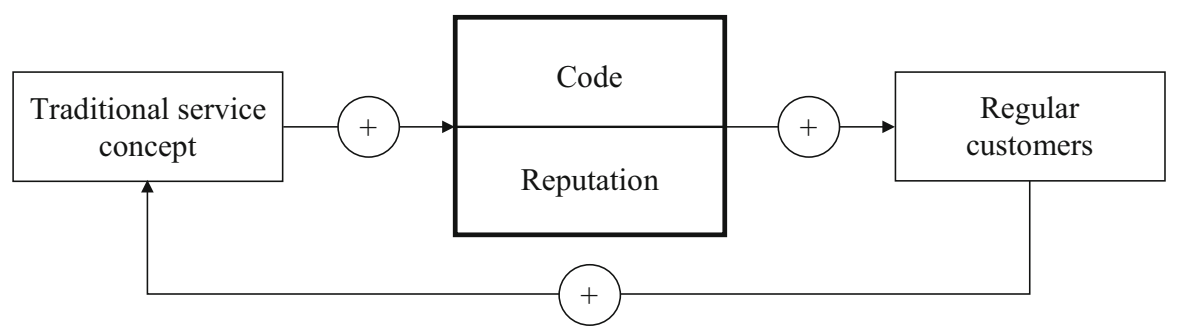

Fig. 4 Strategic pattern and mechanisms 
(Expert 6). Therefore, the organizations avoided giving consumers cost estimates other than by oral communication in the funeral home. In this way, the comparability of offers between different funeral homes was lowered, and the code-as a mechanism to reduce competition in the industry-was reinforced. Because the lack of available information required consumers to rely on past experiences and/or recommendations, the traditional service concept also reinforced reputation as a driver of the pattern. The strategic pattern and the driving mechanisms are summarized in Fig. 4.

The end of the Golden Age of funeral homes began in the 1990s, when the competitive landscape started to change. During this time, so-called "discount funeral homes" entered the market. From the beginning, these new market players attempted to attract consumers with heavy price advertising.

One of the leading [funeral] discounters advertised in the press with an opened coffin and with the slogan, 'The Aldi [low-priced discount retail chain] of funeral homes.' (Expert 2)

Particularly because of the stabilizing nature of the non-aggression pact among incumbents that had facilitated the success of the strategic pattern, such market activities had been unknown in the industry. Although only a few discount players initially entered the funeral market and gained market share slowly, competition intensified when more and more discount funeral homes were opened. The service concept of the discount funeral homes eventually took off by the end of the 1990s in parallel with the emergence of the Internet.

During that time, something emerged that had not existed before: there were [discount] funeral homes that offered funerals on the Internet and sold them supra-regionally. (Expert 12)

With the introduction of Internet offers, discount funeral homes gained a dominant market position and "simply destroyed the funeral industry" (Expert 4). Because of the low visibility of Internet purchases, not even societal norms could prevent consumers from switching to discounters. Because the new market players sold their services supra-regionally, the non-aggression pact among the incumbent funeral homes could no longer guarantee repurchases by regular customers. Thus, the code lost its self-reinforcing attractiveness and "did not play a big role anymore" (Expert 11). Accordingly, competition in this industry turned into "cut and thrust" (Expert 12). Furthermore, press articles increasingly criticized the opacity of the strategic pattern, which destabilized organizational reputation as a central driver. With the fall of these self-reinforcing mechanisms that had ensured the success of the strategic pattern, this pattern failed, as became manifest in the drastic decline in revenue (see Fig. 2).

Despite these threatening developments, "the slowest industry in the entire world" (Expert 6) responded hesitantly to competitive attacks. Once the incumbents felt the urgent need for action along with rapidly declining revenue, they reacted to the crisis in various ways. First, they generated cost reductions primarily through layoffs because "labor costs are one of the largest cost factors that we have" (Expert 4). To facilitate further reductions in end prices, the incumbents followed the 
practices of the discount funeral homes and offered funeral packages that contained fewer elements. As Expert 8 explained, "those offers really are very, very simple, the simplest possible."

Second, the incumbent funeral homes shifted their attention to their reputation. Service reliability became a predominant guideline in interactions with customers to satisfy their needs and to ensure repurchase-even at the expense of current profit margins.

We survive [...] on our regular customers [...] or customers that recommend us because they have received honest advice, for example, because we may have said, 'For cremation, take the simplest coffin.' (Expert 4)

Third, the incumbents hesitantly engaged in marketing activities. In contrast to the discounters' aggressive communication tactics, the incumbents' marketing techniques focused on "search engine optimization" (Expert 1) on the Internet to ensure that they would be found easily by consumers, which "has become entirely normal" (Expert 11) in the industry.

As illustrated in Fig. 5, these changes did not modify the strategic pattern but were instead aimed to retain it. The incumbents compensated for the decay of thealbeit never entirely abolished-code by strengthening organizational reputation as the driving mechanism. Accordingly, marketing activities were not designed to aggressively acquire new customers but to communicate a desirable reputation for reliable service (e.g., "Established since...") to convert reached consumers into regular customers before competitors could do so. However, the focus on reputation did not lead to a clear-cut differentiation between competing funeral homes because "the people come to us because they know that they will be well served-which applies to most funeral homes" (Expert 8). Furthermore, cost reductions changed very little about the traditional service concept except for the elimination of service components in complementary low-cost packages.

Although the reactions to the crisis led to a temporary upswing in revenues (see Fig. 2), any positive outcome of these efforts collapsed down when consumers' financial scope was reduced by the abolition of funeral allowances in 2004.

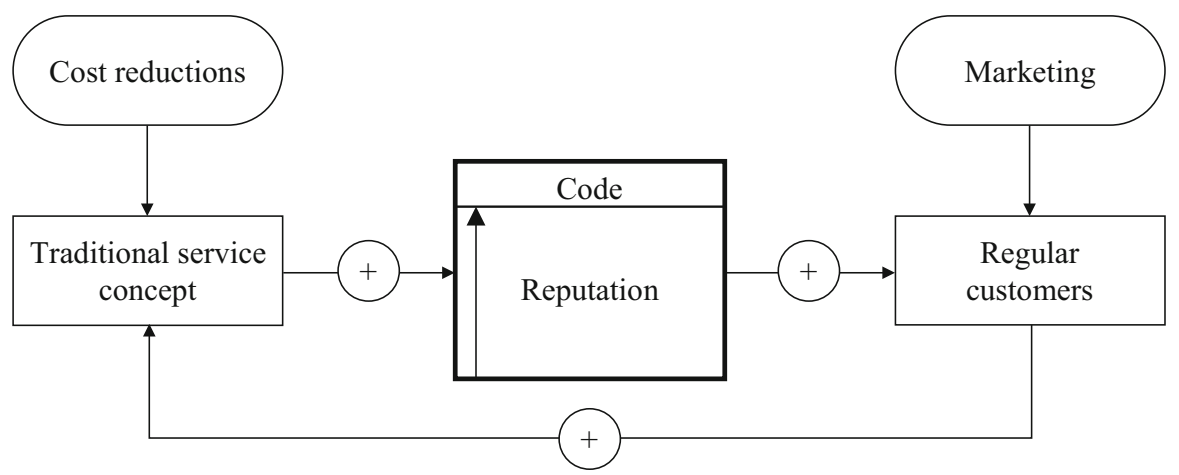

Fig. 5 Reactions to the crisis 
Although the funeral homes perceived this event as a critical "upheaval in the market" (Expert 1), they did not react to this market change any differently despite the intensification of the crisis: revenues in the funeral industry in Berlin dropped even further and have never recovered (see Fig. 2). Along with the path-dependent dynamics described above, this development indicates that the organizations had entirely forfeited their scope of action and did not perceive any strategic alternatives (Koch 2008, 2011).

\subsection{Strategic premises}

Paths essentially become frozen because strategic premises remain uncontested (Rothmann 2013; Tripsas and Gavetti 2000). To illustrate how strategic premises are stabilized despite the intense forces of organizational crises, I reconstruct the underlying premises in the following section. Because organizational perceptions of the environment may not be understood without reflecting on the premises that organizations have about themselves, I first describe the self-understanding of incumbent organizations in the focal industry (Porac and Thomas 1989).

\subsubsection{Organizational self-understanding}

The incumbent funeral homes in Berlin perceived themselves to offer services based on two types of competences. First, they relied on a technical competence that they leveraged to arrange professional burials. Because these funeral homes primarily operated as agencies that took orders from customers and forwarded them to subcontractors, burial was predominantly a coordinative "office job" (Expert 8) that required funeral directors to "make phone calls or write emails" (Expert 4).

Second, the incumbent funeral homes leveraged a counseling competence that was targeted at finding a form of funeral that would best match a consumer's needs. Consistent with the complexity of funeral services due to the combination of numerous elements, the counseling appointment was viewed as central to the entire service process. As Expert 8 explained, "there are many small pieces that need to be discussed [...]. That's what I'm here for."

The complexity of the provided service seemed to require a direct and personal contact with customers in time-consuming counseling appointments. Therefore, the funeral homes could leverage their counseling competence to achieve quasipermanent customer retention because "those who return after 5 years often want to talk to the same advisor, particularly because they had revealed many intimate details" (Expert 1). Consequently, the funeral homes predominantly defined themselves by referring to their counseling competence- "the noblest task" (Expert 4)-because it reproduced reliable results over time consistent with the very definition of a competence (Schreyögg and Kliesch-Eberl 2007).

\subsubsection{Strategic premises about the environment}

The incumbents primarily ascribed the persistence of discount funeral homes to societal developments: the perceived "disposal mentality, the wave on which the 
discount funeral homes swim" (Expert 12). Accordingly, the incumbents perceived a general attitude of disinterest in decent funerals and a tendency to demand inexpensive funerals in line with the motto "the cheaper, the better" (Expert 4). The incumbents described this decay of values as "a regional thing" (Expert 13) because vast parts of the population in Berlin had broken away from the religious traditions and values that had formed social cohesion. In the resulting vacuum of anonymity, social pressures were virtually non-existent.

There are no societal norms anymore that determine a certain standard, such that I would have to be careful that I don't do anything wrong because others would talk about it. (Expert 1)

The funeral homes perceived that these social pressures determined the extent to which consumers would be willing to pay for funerals: with the decay of societal norms, customers were offered "the simplest coffin [if] no one will see it" (Expert 4). Due to the perceived connection between social pressures and consumer choice, the funeral homes conceived that there would be a low willingness to pay for funerals due to the decay of social pressures. They perceived these shifts even across institutional frameworks, as highlighted in the following:

There are differences between [Berlin's] districts. [...] But the trend is the same in these areas: [a funeral] should not cost anything anymore. (Expert 8)

However, the premise of a low willingness to pay was not only based on a lack of social pressure. With the final abolishment of funeral allowances in 2004, consumers had to pay the full cost of funerals. Accordingly, the funeral homes expected a further decline in willingness to pay because "if someone else pays, you don't look at the money" (Expert 13), but consumers supposedly did once the financial aid disappeared. However, the premise of a low willingness to pay for funerals was not exclusively connected to consumers' financial scope because consumers were believed to prefer cheap funerals "even if grandma has saved money in a savings account" (Expert 4).

This belief in consumers' low willingness to pay was nurtured by a second strategic premise: consumers were perceived to have no idea of the benefits of a decent funeral.

It plays a role that [consumers] do not understand: what does it mean that someone dies? What is a grave? What does this have to do with reverence? (Expert 8)

Thus, consumers were perceived to have little knowledge of the topics of death and dying. This resulted from a lack of prior experience due to long repurchase cycles and the lack of the legitimacy of an open discourse in society. Accordingly, the incumbents perceived that consumers would "not want to talk about this topic" (Expert 6) between deaths, which explained the industry's hesitance toward preorder marketing activities. Furthermore, this premise of consumer "nescience" implied that the funeral homes' central counseling competence unfolded its value. In this way, the funeral homes could leverage their counseling competence, which constituted their identity as experts who understood the daily realities of funerals, 
or, as Expert 5 stated, "the view that funeral directors have is not the view that the bereaved have."

The pre-condition of consumer nescience of funeral homes' core competence reveals the dilemma in which the funeral homes were trapped. On the one hand, they were not interested in comprehensively informing consumers ex-ante of funeral services because their counseling competence would have become worthless. On the other hand, consumer nescience implied that willingness to pay would be low due to a lack of appreciation for funeral services. However, the non-transparent pricing policies revealed that the perceived willingness to pay varied depending on the elements of the services.

Taking care of the dead-this is a service that we can directly bill. [...] We can bill [the other components of the funeral service] on an hourly basis, but many funeral directors are concerned that customers will say, 'What is this supposed to cost? Thirty or 40 Euros per hour? Okay, I'll do this myself.' Therefore, there are still many funeral directors who [...] place a large profit margin on the coffin and do not list other components on the bill at all. (Expert 1)

Thus, as perceived by the incumbents, uninformed consumers had a low willingness to pay for funeral services and informed consumers were even more unwilling to pay. Whereas consumers seemed to accept payments related to funeral homes' technical competence, the organizations needed to finance all of their other activities, including those related to their counseling competence, primarily "by selling the coffin" (Expert 4). The funeral homes reacted to the crisis consistently by retaining the traditional service concept and, apart from the coffin, excluding peripheral components. In this way, their technical competence gained value as a result of the very existence of the strategic premise of a low willingness to pay to the extent that organizational competences and corresponding strategic premises mutually enforced and reinforced each other.

As illustrated in Fig. 6, this arrangement ensured that strategic off-path alternatives were eliminated from the scope of action: although the willingness to pay for funeral services was assumed to be low, "people in this country are willing

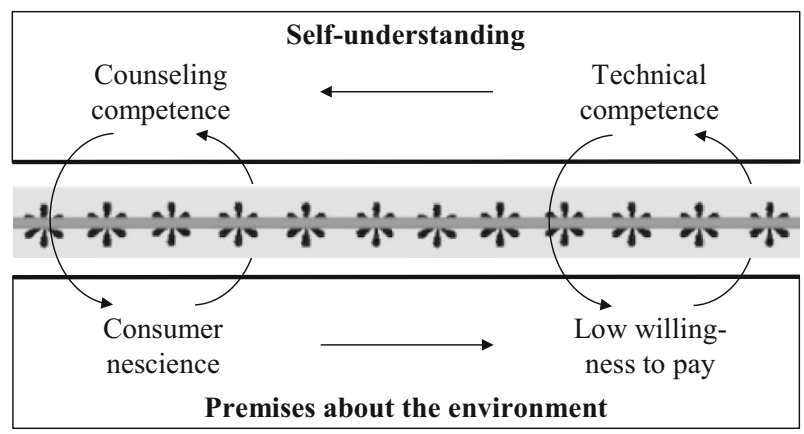

Fig. 6 Strategic premises and path stabilization 
to pay, even for strange service offers" (Expert 5). Thus, a "differentiation strategy" of providing added value through innovative services for which customers would be willing to pay would have been a promising alternative to recover and sustain rents in this market (Breuer and Daumann 2010; Porter 1980). Although the funeral industry was (and still is) highly regulated and dependent on subcontractors, the legal framework and the assembly of services provided by suppliers granted a broad scope for creativity to provide added value because "anything is possible with regard to funerals" (Expert 6).

\subsection{The stabilization of strategic premises}

The mutually reinforcing strategic premises of the organizations about their selfunderstanding and consumers excluded off-path activities from the scope of action and remained uncontested over the focal period. In the following section, I provide insights into the stabilization of these premises despite the intense crisis that struck the industry.

\subsubsection{Tapering market feedback}

Although widespread media coverage on issues related to the funeral industry provided considerable feedback that signaled the need for an update of strategic premises, there was still a large potential for myopic blind spots. In particular, the incumbents' strong position during the successful Golden Age was accompanied by the blinding effects of complacency that became a burden during the period of interest. This became particularly evident when the discounters entered the market: because the incumbents ascribed neither a counseling competence nor a technical competence to the new market players and, therefore, reasoned that "this [was] not a funeral home" (Expert 5), they were hesitant to react to the changed competitive landscape. These effects of complacency were amplified by the structural peculiarities of the market environment. In particular, the long repurchase cycles between deaths seemed to play a critical role.

Last week, a person called me and said, 'I just wanted to check this number.

We dealt with each other in the 1980s the last time and I just wanted to see whether your company still exists.' (Expert 13)

Such infrequent interactions between deaths inhibited the absorption of timely market feedback directly from customers. Therefore, feedback "also reaches the funeral industry but, of course, with a delay of 10 years" (Expert 6).

Furthermore, the funeral homes' peculiar collaborations with suppliers aggravated this effect. Because the funeral homes handed over most of the service delivery to subcontractors, customer contact was reduced to the counseling appointment and a few phone calls at the beginning of the value chain; thus, "the burial happens without the presence of the funeral director" (Expert 4). Because the funeral homes could not obtain feedback after funerals, they had to rely on feedback from repurchases, which seemed to result in distorted perceptions. 
They call me again and again. Of course, you never know who does not call [me], right? (Expert 4)

Because the funeral homes seemed unable to trace the customers who did not return, they could only obtain feedback from those customers who did return. However, their feedback hardly seemed to disconfirm strategic premises because "there is hardly anyone who says, 'I did not like what we did 20 years ago"" (Expert 8). Because customers in the funeral industry in Berlin "hardly ever complain but it is possible that they will never return" (Expert 13), it seemed hardly possible for negative feedback to reach the funeral homes. Such tapered market feedback appeared to minimize doubts about the timeliness of strategic premises.

\subsubsection{Rectifying market feedback}

Even when negative feedback reached the organizations, it did not necessarily result in a contestation of their strategic premises despite the intensity of the industry's crisis. Instead, the organizations interpreted market feedback in a way that reinforced their strategic premises. From an observational perspective, certain environmental changes could have been interpreted and enacted differently, as illustrated by a comment on the social pressures in rural areas:

The neighbors will also attend the ceremony. [Thus, the bereaved says,] 'I don't want to attract attention. It shouldn't be too cheap and it shouldn't be too exotic.' They try to muddle through and, unfortunately, don't choose what they would have preferred. (Expert 6)

Thus, the reduction of social pressures in Berlin entailed individualized freedom of choice for consumers, which could have broadened the range of variety for innovative off-path activities. However, this societal development was interpreted consistently with proprietary assumptions of a low willingness to pay to the extent that the incoming feedback did not disconfirm the organizations' strategic premises, allowing them to retain these premises.

Beyond that, the organizations provided various normative reasons to retain their strategic pattern in reference to their strategic premises. Most notably, the premise of a low willingness to pay entered the discourse in two ways. In the context of declining conventional funerals, customers were perceived to be liable to a decay of values consistent with the "disposal mentality." In the context of innovative strategic alternatives, consumers were described as so strongly value-affiliated that they would reject innovative offers. As Expert 6 stated,

Dealing with death, mourning, dying, funerals ... all people become conservative again. (Expert 6)

Based on this logic, the funeral homes hardly seem to have referred to the same consumers in these two contexts, as neither the buyers of discount funerals could be termed as "value-affiliated," nor could the "conservative" consumers conceive discount funerals to be appropriate. However, with such narrative inflections, the 
funeral homes could rationalize the established pattern and eliminate any need for questioning their strategic premises.

\subsubsection{Framing consumer choice}

Such interpretations of, and responses to, feedback constitute reflexive modes of stabilizing established strategic premises. However, the funeral homes also engaged in market activities that produced reinforcing market outcomes, as illustrated below:

If the funeral director has 16 coffins in his show room with 15 made of oak or pine and a palm-leaf carving and one that is halfway modern ... it's a foreign particle, exotic: no consumer would dare to take that one. (Expert 6)

Thus, the incumbents pre-selected their offers prior to presenting them to consumers. This pre-selection occurred not only as described by physically presenting only certain items but also by arranging catalogues that served as the basis for assembling the service. Because the strategic pattern was oriented toward satisfying regular customers, such pre-selections were guided by the consideration of whether "this [new service component would] fit with my customer target group" (Expert 12). Thus, strategic premises about consumer needs essentially predetermined which service packages would be offered to consumers. Because of the peculiar situation in which "the [consumers] are frequently [...] distressed [and] don't know what they want" (Expert 6), such pre-selection could essentially guide consumer choice. Accordingly, based on the premise of a low willingness to pay for additional service items or innovative components that would yield higher profit margins, "most [funeral homes] would probably say, 'I can't sell [these items]", (Expert 10), with the consequence that these alternatives were excluded from the scope of action. Such guiding pre-selections generated market outcomes that would not disconfirm strategic premises, although consumers presumably had freedom of choice.

In addition to physical pre-selections, funeral homes could also set narrative frames by using their counseling competence. For instance, by asking " "which coffin do you prefer, this one or that one?,' I guide [consumers] to making a decision. And they cannot say, 'yes' or "no'" (Expert 4). This principle seemed to work similarly for the organization of further components of the funeral ceremony:

[Simulating a conversation with a customer] It's your funeral ceremony. If you want to have a priest, you'll get one. Even if you don't go to church, we know various priests who don't care whether you go to church or not. (Expert 12)

Thus, independent of customers' religious denomination, the traditional service concept was not questioned and, therefore, the resulting orders of the base of regular customers, albeit "diminishing" (Expert 6), did not provide any reason to update strategic premises. In this way, the funeral homes "guide [consumers] through this time of farewell like operators of a river lock-and there, [they] can exert influence" (Expert 5). 


\subsubsection{Shaping consumer choice}

Framed consumer choice essentially produced reinforcing market outcomes when consumers were unable or unwilling to search for alternatives on their own. However, even if consumers actively approached incumbent funeral homes with more innovative ideas beyond the traditional service concept, their realization was anything but certain.

[On innovative ideas] We inform and give advice and say, 'Does this make sense?' [...] I would somehow attempt to persuade everyone that this is actually nonsense. (Expert 13)

Thus, as self-appointed experts in the funeral industry, the incumbents "guide people during the counseling appointment to where [they] want to have them" (Expert 4) by leveraging their counseling competence to deter consumers from innovative ideas. Because they were programmed to provide a reliable service to facilitate repurchases on later occasions, they gave advice by enacting their premises about consumers. Because consumers were perceived to have a low willingness to pay for services beyond the technical part of a funeral, the funeral homes hoped to be rewarded by dissuading them from higher-priced offers and, instead, recommending lower-priced services, e.g., "very simple coffins" (Expert 13) for cremations. In this way, consumers' low willingness to pay seemed to have become "a self-made problem" (Expert 6): by heavily promoting low-priced offers that conformed to their own strategic premises, the funeral homes seemed to have contributed to the very emergence of a low willingness to pay and "destroyed the market themselves" (Expert 6). Thus, consumers could not only be deterred from choices that would disconfirm strategic premises but consumer choice could also be made compatible.

Sometimes, the ideas are a bit odd. Then, you surely need to bring them into a straight line. (Expert 8)

By aligning consumer choice with the traditional service concept, the organizations produced market outcomes that did not disconfirm their strategic premises, and the need for an update was eliminated.

\section{Discussion}

The case of the path-dependent incumbents in the funeral industry in Berlin illustrates how the underlying premises of strategic paths may be retained and stabilized despite the shock-inducing forces of crises. Thus, the present study challenges the central assumption of research on path dependence and incumbents' rigidities in the face of changes in the environment that the reception of strongly negative feedback through an organizational crisis leads to an update of strategic premises (e.g., Levinthal and March 1993; Vergne and Durand 2010, 2011). Because "path dependence cannot be exhaustively described by a set of theoretical propositions [but] is located in the realm of mechanism-based theorizing" (Dobusch 


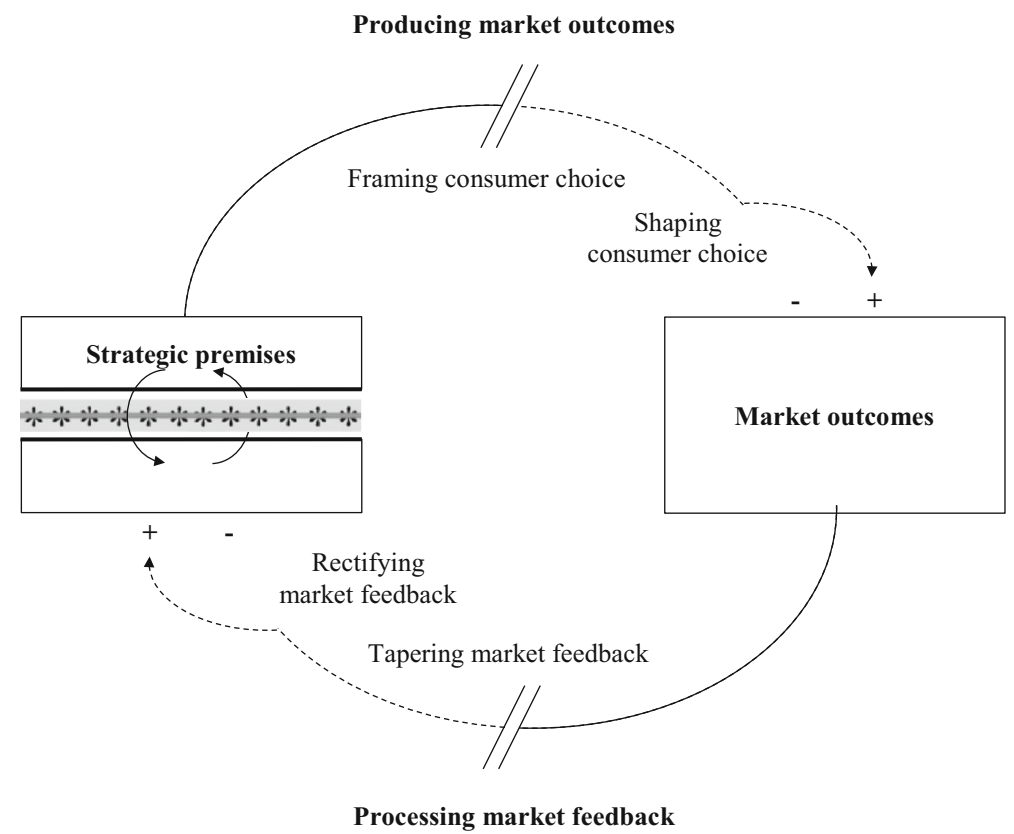

Fig. 7 The stabilization of strategic premises

and Kapeller 2013: 291 et seq., emphasis in original; see also Durand and Vaara 2009), I theoretically distilled mechanisms that stabilize strategic premises in lockins, even in times of crisis. As illustrated in Fig. 7, this study indicates that strategic premises may be stabilized by (1) tapering market feedback; (2) rectifying market feedback; (3) framing consumer choice; and (4) shaping consumer choice. Thus, a contribution that this work offers is to provide tentative insights into the stabilization of strategic premises in lock-ins, which has not been fully explored to date despite the powerful insights into the pathological reproduction of paths that it provides (Geiger and Antonacopoulou 2009; Dobusch and Schüßler 2013; Rothmann and Koch 2014). The identification of these mechanisms also has broader theoretical implications for the concept of path dependence and the literature on incumbents' rigidities in the face of changes in the environment. I present and discuss these implications in the following.

\subsection{Processing market feedback: disconfirming feedback and the contestation of strategic premises}

The findings of the present study indicate that the way path-dependent organizations process feedback may stabilize strategic premises. In particular, I identified the reduction and modulation of incoming market feedback-i.e., tapering market feedback and rectifying market feedback - as stabilizing mechanisms. The evidence of this study suggests that these theorized mechanisms seem to filter out deviant 
market feedback and lead to a re-interpretation of received signals to create coherence with strategic premises. Consequently, incoming feedback hardly seems to disconfirm the strategic premises in place. Therefore, these mechanisms seem to reduce the perceived need for an update of strategic premises.

These findings reinforce well-known ideas of "myopia" through a pathconfirming organizational context that avoids deviant feedback (e.g., Eggers and Kaplan 2013; Geiger and Antonacopoulou 2009; Koch 2011). However, the presented findings extend beyond these ideas: while these works predominantly suggest that organizations with deeply engrained strategic premises seem to filter out weak signals of a misfit with the environment but hardly ignore the strongly negative feedback generated by a crisis, the presented findings suggest that strongly negative feedback does not serve this disruptive function in all cases (Schreyögg and Kliesch-Eberl 2007). Instead, path-dependent organizations may process feedback in such a way that strategic premises are not disconfirmed. Thus, this study coincides with Koch et al.'s (2009) assertion that the myopia-focused discourse on failed adjustments of strategic premises in the literature on incumbents' rigidities and path dependence may not fully reflect the complexity of the processes involved-especially in times of crisis. I offer a step toward increasing complexity in theorizing this phenomenon by identifying underlying mechanisms that lead to the retention of strategic premises despite strongly disconfirming feedback through organizational crises. These findings suggest that strongly disconfirming feedback as such may not necessarily lead to a contestation of strategic premises; an update of strategic premises seems to depend on how pathdependent organizations process this feedback. Based on my evidence, it appears that the identified mechanisms of processing market feedback tightly constrain the possibilities of updating strategic premises because of the avoidance or modulation of deviant feedback that severe organizational crises generate. Thus, this study offers a more nuanced understanding of the avoidance of updating strategic premises through disconfirming feedback in lock-ins that extends beyond the holistic ascription of myopia.

\subsection{Producing market outcomes: the generative influence of path- dependent organizations on their environment}

Whereas these forms of processing market feedback constitute reflexive modes of stabilizing strategic premises, the presented findings suggest that path-dependent organizations may also rely on a set of generative modes for this purpose. Based on my evidence, it appears that these mechanisms produce market outcomes that stabilize strategic premises. In particular, I identified the exclusion of, and active interventions against, undesired offers in interactions with consumers as two further mechanisms that stabilize strategic premises, i.e., framing consumer choice and shaping consumer choice. The findings indicate that these theorized mechanisms seem to be aimed at generating market outcomes that create coherence with strategic premises. Consequently, the perceived market outcomes hardly seem to disconfirm strategic premises. Therefore, the production of market outcomes in line 
with strategic premises seems to reduce the perceived need for an update of these premises.

The presented findings indicate that the affected organizations did not necessarily act with unsound intentions. Instead, they were guided by their strategic premises about consumers, i.e., what they thought consumers wanted, in their hope of being rewarded through repurchases (Tripsas 2009). Thus, in line with the retained premise of a low willingness to pay, the funeral homes gutted their offers in response to the crisis and promoted these offers in counseling appointments, which seems to have contributed to the tense market situation in the funeral industry in Berlin. Accordingly, these findings provide evidence supporting the view that, in contrast to stochastic processes in technological contexts, path dependence in managerial contexts seems to be a social process that is endogenously created in and though organizations' own decisions and actions (Duschek 2010; Greve and Seidel 2014; Koch 2011; MacKay and Chia 2013; Sydow et al. 2009). However, the presented findings extend beyond this idea of path dependence to the extent that they emphasize the generative influence that path-dependent organizations may have on their environment. While the extant literature on path dependence and related research predominantly focuses on the reception and enactment of positive feedback from market outcomes, the findings in the present study indicate that pathdependent processes may not only be affected by the environment in which they are embedded (Dobusch and Schüßler 2013; Koch et al. 2009); rather, path-dependent organizations may also conversely shape their environment to a certain extent (see also Burgelman 1991; Child 1997). With that, the study indicates that the strategic premises of path-dependent organizations may not only "self-perpetuate", as the literature on incumbents' rigidities and path dependence suggests (e.g., Gilbert 2006; Miller 1994; Koch 2011). Instead, path-dependent organizations may also generatively produce market outcomes that reduce the need for an update of strategic premises. Thus, the presented findings open the theoretical perspective for the endogenous creation of market outcomes in path-dependent processes that extend beyond the enactment of received feedback in strategic decisions.

\subsection{Agency and path reproduction}

Opening the theoretical perspective for a generative role of path-dependent organizations, i.e., the production of market outcomes, inherently leads to the question of agency in path-dependent processes. Whereas framing and shaping consumer choice seemed to occur partly "behind the backs" (Sydow et al. 2012b: 155) by following strategic premises in the presentation and promotion of offers, a more active role in directing consumer choice may not entirely be excluded. If the existence of agency may be assumed at least to a certain extent, the main question then is how path-dependent organizations use their agency.

In contrast to "path creation," which addresses intentional deviations from established strategic patterns, this study reveals the (at least partially) mindful reproduction of strategic patterns by producing market outcomes that do not disconfirm the underlying strategic premises (Garud and Karnøe 2001). In line with previous studies, this paper highlights the constraining forces of strategic premises 
in conducting strategic change when the premises remain uncontested (e.g., Rothmann and Koch 2014; Tripsas 2009; Tripsas and Gavetti 2000). Accordingly, this study provides further evidence that the counterfactual reproduction of paths may not simply be a "failure to act" (Weick 1979: 149). Instead, the organizations invested tremendous efforts to respond to the crisis, but these were reminiscent of "the dynamics of standing still" (Sull 1999): the responses were aimed at restoring the efficiency of the formerly successful strategic pattern and improved the economic situation in the short run but were unsuccessful in the long run (see also Gilbert 2005; MacKay and Chia 2013; Rothmann and Koch 2014). While prior works rely mainly on resource-based and routine-based reasons to explain this phenomenon and holistically refer to uncontested strategic premises as the root of lacking deviations from the path, this study develops complementary insights (e.g., Eggers and Kaplan 2013; Gilbert 2005, 2006; Tripsas and Gavetti 2000): by identifying mechanisms that stabilize strategic premises in lock-ins even in times of crisis, this study sheds further light on how and why organizations that are affected by "the dynamics of standing still" retain their strategic premises despite the strongly disconfirming feedback that their crisis generates and only conduct slight adjustments to their strategic pattern.

By identifying the production of market outcomes as one cluster of mechanisms that stabilize strategic premises to reproduce the path, the present study provides indications of how path-dependent organizations may use agency if it is assumed to exist in path-dependent processes: if strategic premises are deeply engrained, pathdependent organizations with such entrenched premise structures hardly seem to use their agency to break, or possibly even to create a new, but instead to "extend" the path by producing market outcomes that coincide with the path's underlying strategic premises. In fact, the presented findings correspond with prior accounts of path extension to the extent that the incumbent funeral homes continuously conducted strategic activities that are closely related to the established strategic pattern (Duschek 2010; Meyer and Schubert 2007; Sydow et al. 2012a). However, while these works have emphasized path extension as a form of "strategic path management" to keep the path alive (e.g., Duschek 2010), this study presents the case of a self-destructive "extension" of the path in times of crisis. Because the very production of market outcomes in line with strategic premises-especially of a low willingness to pay-seemed to have intensified the critical market situation, the reproduction of the path became even more a burden and eventually led to a situation in which the funeral homes seemed to "bury themselves." Thus, by presenting indicative empirical evidence of how the underlying strategic premises are stabilized and how these premises inhibit the realization of strategic alternatives, this study sheds further light on the pathological reproduction of paths despite fierce organizational crises (Sydow et al. 2012a). With that, this study offers a tentative step forward in "[t]he ongoing process of building a theory of disruption" (Christensen 2006: 39) that attempts to illuminate incumbents' challenges to conduct strategic change in the face of changes in the environment (Eggers and Kaplan 2013; O’Reilly and Tushman 2013; Tripsas 2009). 


\subsection{Additional research questions}

While the presented findings offer a number of theoretical contributions to the literature on path dependence and related research, these findings also raise a number of interesting questions for future research. The question of generalizability certainly is an important one. As with all case studies, the qualitative data on which the findings of this study are based did not permit statistical generalization but instead required theorizing efforts via theoretical abstraction to achieve analytical generalization (Yin 2014). Accordingly, I abstracted from the case of incumbent organizations in the funeral industry by theoretically distilling mechanisms of premise stabilization. While such a unique and extreme case, a "talking pig," is compelling for such theorizing efforts because the studied phenomena may be better observed, it may impose the challenge that the generated theoretical insights are hardly transferrable to other contexts (Lincoln and Guba 1985; Siggelkow 2007). However, a remarkable number of prior studies have identified similar patterns of premise stability, path reproduction, and disruption in a broad range of contexts, such as the automotive industry, the airline industry, the book industry, the camera industry, the cash register industry, the music industry, the newspaper industry, the tire industry, and the typesetter industry (Koch 2011; Kunow et al. 2013; MacKay and Chia 2013; Maielli 2015; Miller and Chen 1994; Rosenbloom 2000; Rothmann and Koch 2014; Schreyögg et al. 2011; Sull 1999; Tripsas 1997; Tripsas and Gavetti 2000). Furthermore, Schreyögg and Kliesch-Eberl (2007) presumed that pathdependent organizations that face a crisis seem to have a genuine interest in enabling the reproduction of their path by producing desired market outcomes and that processing feedback seems to play an important role in dealing with strategic premises. In that sense, the findings on how organizations stabilize strategic premises may be transferrable to path-dependent organizations in crises in different contexts (Lincoln and Guba 1985). However, based on the analysis in this study, it may not be concluded that organizations that stabilize strategic premises must necessarily be path-dependent (Schultz and Hernes 2013); path dependence is just one among several forms of organizational stability (Sydow et al. 2009). Thus, while the present study focuses on path-dependent organizations that have entered a crisis because of severe path disruptions, future research may explore whether these findings also apply to organizations that are not path-dependent.

Another question concerns the lack of variation among organizations in the analyzed industry. Consistent with path dependence as a macro-level theory, the joint analysis of incumbent organizations in the funeral industry, which hardly differed with regard to their strategic activities and premises, as a holistic single case did not seem to inhibit the study of the phenomenon of interest (Becker 2004; Breuer and Daumann 2010; Burgelman 2010; Klein et al. 1994; Yin 2014). Several prior studies have also observed such convergence of path-dependent organizations in other mature industries, even across institutional frameworks (e.g., Benner and Tripsas 2012; Flier et al. 2003; Kunow et al. 2013; Lampel and Shamsie 2003; Rothmann and Koch 2014; Vergne and Durand 2011). The findings of the present study indicate that such convergence may be the result of positive feedback mechanisms that unfold their effects across organizational boundaries. Particularly 
the code, a "coordination mechanism" that required the incumbent funeral homes to rely on regular customers within their catchment area, seems to have contributed to a form of territorial "market differentiation" and reduced the need for "product differentiation" (Porter 1980; Sydow et al. 2009). However, within the scope of this paper, I was not able to fully reconstruct the origin of this convergence. Understanding these puzzling convergence phenomena in mature industries would essentially contribute to explaining the emergence of these industries (Benner and Tripsas 2012). Therefore, future research may consider exploring the origins of this convergence in more detail.

Furthermore, the lack of convergence among incumbent funeral homes inhibited a multiple-case design (Eisenhardt 1989). This research design would have been required to extend the case analysis beyond the exploration of mechanisms that stabilize strategic premises by reconstructing the contingent factors through which the explored mechanisms come into effect (Gilbert 2006); i.e., while the single-case design of this study seemed to be particularly suitable to theoretically distill mechanisms that stabilize strategic premises in lock-ins even in times of crisis, the study abstracts away the contingent factors that trigger the explored mechanisms (Klag and Langley 2013; Siggelkow 2007; Langley and Abdallah 2011). However, as Eggers and Kaplan (2013) denoted, empirical phenomena that relate to path dependence and other forms of incumbents' rigidities are highly complex and require researchers to shed light on these phenomena in a tentative and ongoing process (see also Christensen 2006). The present study's emphasis on exploring mechanisms that stabilize strategic premises complies with the need for developing mechanism-based answers to the questions of 'how' and 'why' in organization and management research in general and the dynamics of managerial scope of action in particular (e.g., Anderson et al. 2006; Dobusch and Kapeller 2013; Langley et al. 2013). To shed further light on the stabilization of strategic premises in which strategic paths are embedded, I encourage future research to use a multiple-case design to explore contingency effects that illuminate under which conditions the mechanisms that stabilize strategic premises come into effect.

Finally, while this study highlights the fruitfulness of exploring mechanisms that stabilize strategic premises in the context of path dependence, these mechanisms of stability may reveal their dual character as mechanisms of change under certain conditions (Farjoun 2010). For example, Schmidt and Keil (2013) emphasized that organizations may shape consumer choice to create a willingness to pay for innovations and, therefore, generate strategic alternatives to the established strategic pattern. Similarly, tapered market feedback may provide the necessary distance from current consumer expectations that opens the scope of action for developing strategic alternatives (Danneels 2003). Thus, the explored mechanisms that stabilize the underlying strategic premises of a path and lead to its reproduction may also contribute to changing these premises and opening the scope of action, i.e., these mechanisms may also help organizations break their path. Because research on path-breaking activities remains scarce, an exploration of the conditions under which the mechanisms that stabilize strategic premises eventually turn into mechanisms of premise change may contribute valuable insights to the field of 
research on path dependence (Garud et al. 2010; Kunow et al. 2013; Sydow et al. 2009).

Acknowledgments The author would like to thank Business Research Department Editor Thomas Hutzschenreuter and the two anonymous reviewers for their helpful advice to improve this manuscript. The author is also indebted to Leonhard Dobusch, Johann Fortwengel, Arne Keller, Jochen Koch, Wasko Rothmann, Thomas Schmidt, Georg Schreyögg, Jörg Sydow, and Heinz-Theo Wagner for their thoughtful comments on earlier versions of this manuscript. Furthermore, the author thanks the Dieter Schwarz Foundation for funding this research project.

Open Access This article is distributed under the terms of the Creative Commons Attribution 4.0 International License (http://creativecommons.org/licenses/by/4.0/), which permits unrestricted use, distribution, and reproduction in any medium, provided you give appropriate credit to the original author(s) and the source, provide a link to the Creative Commons license, and indicate if changes were made.

\section{References}

Akyel, Dominic. 2013. Die Ökonomisierung der Pietät. Der Wandel des Bestattungsmarktes in Deutschland. Frankfurt am Main: Campus.

Albert, Stuart, and David A. Whetten. 1985. Organizational identity. Research in Organizational Behavior 7: 263-295.

Anderson, Peter J.J., Ruth Blatt, Marlys K. Christianson, Adam M. Grant, Christopher Marquis, Eric J. Neuman, Scott Sonenshein, and Kathleen M. Sutcliffe. 2006. Understanding mechanisms in organizational research: Reflections from a collective journey. Journal of Management Inquiry 15(2): 102-113.

Arthur, W.Brian. 1989. Competing technologies, increasing returns, and lock-in by historical events. Economic Journal 99: 116-131.

Becker, Marcus C. 2004. Organizational routines: A review of the literature. Industrial and Corporate Change 13(4): 643-677.

Benner, Mary J., and Mary Tripsas. 2012. The influence of prior industry affiliation on framing in nascent industries: The evolution of digital cameras. Strategic Management Journal 33(3): 277-302.

Bingham, Christopher B., and Steven Kahl. 2014. Anticipatory learning. Strategic Entrepreneurship Journal 8(2): 101-127.

Breuer, Markus, and Frank Daumann. 2010. Der Bestattungsmarkt in Deutschland. Jahrbuch für Wirtschaftswissenschaften 60(3): 227-253.

Burgelman, Robert A. 1991. Intraorganizational ecology of strategy-making and organizational adaptation: Theory and field research. Organization Science 2(3): 239-262.

Burgelman, Robert A. 1994. Fading memories: A process theory of strategic business exit in dynamic environments. Administrative Science Quarterly 39(1): 24-56.

Burgelman, Robert A. 2002. Strategy as vector and the inertia of coevolutionary lock-in. Administrative Science Quarterly 47(2): 325-357.

Burgelman, Robert A. 2010. Strategic consequences of co-evolutionary lock-in: Insights from a process study. In The hidden dynamics of path dependence: Institutions and organizations, ed. Georg Schreyögg, and Jörg Sydow, 233-248. London: Palgrave Macmillan.

Calori, Roland. 2002. Real time/real space research: Connecting action and reflection in organization studies. Organization Studies 23(6): 877-883.

Child, John. 1997. Strategic choice in the analysis of action, structure, organizations and environment: Retrospect and prospect. Organization Studies 18(1): 43-76.

Christensen, Clayton M. 2006. The ongoing process of building a theory of disruption. Journal of Product Innovation Management 23(1): 39-55.

Christensen, Clayton M., and Joseph L. Bower. 1996. Customer power, strategic investment, and the failure of leading firms. Strategic Management Journal 17(3): 197-218. 
Clark, Shawn M., Dennis A. Gioia, David J. Ketchen, and James B. Thomas. 2010. Transitional identity as a facilitator of organizational identity change during a merger. Administrative Science Quarterly 55(3): 397-438.

Dacin, M.Tina, Kamal Munir, and Paul Tracey. 2010. Formal dining at Cambridge Colleges: Linking ritual performance and institutional maintenance. Academy of Management Journal 53(6): 1393-1418.

Danneels, Erwin. 2003. Tight-loose coupling with customers: The enactment of customer orientation. Strategic Management Journal 24(6): 559-576.

Danneels, Erwin. 2011. Trying to become a different type of company: Dynamic capability at Smith Corona. Strategic Management Journal 32(1): 1-31.

David, Paul A. 1985. Clio and the economics of QWERTY. American Economic Review 75(2): 332-337.

Dobusch, Leonhard, and Jakob Kapeller. 2013. Breaking new paths: Theory and method in path dependence research. Schmalenbach Business Review 65(3): 288-311.

Dobusch, Leonhard, and Elke Schüßler. 2013. Theorizing path dependence: A review of positive feedback mechanisms in technology markets, regional clusters, and organizations. Industrial and Corporate Change 22(5): 617-647.

Durand, Rodolphe, and Eero Vaara. 2009. Causation, counterfactuals, and competitive advantage. Strategic Management Journal 30(12): 1245-1264.

Duschek, Stephan. 2010. Strategisches Pfadmanagement: "Beyond Path Dependence". Managementforschung 20: 223-259.

Dutton, Jane E., and Janet M. Dukerich. 1991. Keeping an eye on the mirror: Image and identity in organizational adaptation. Academy of Management Journal 34(3): 517-554.

Eggers, J.P., and Sarah Kaplan. 2013. Cognition and capabilities: A multilevel perspective. Academy of Management Annals 7(1): 295-340.

Eisenhardt, Kathleen M. 1989. Building theory from case-study research. Academy of Management Review 14(4): 532-550.

Farjoun, Moshe. 2010. Beyond dualism: Stability and change as a duality. Academy of Management Review 35(2): 202-225.

Flier, Bert, Frans A.J. Van den Bosch, and Henk W. Volberda. 2003. Co-evolution in strategic renewal behaviour of British, Dutch and French financial incumbents: Interaction of environmental selection, institutional effects and managerial intentionality. Journal of Management Studies 40(8): 2163-2187.

Garud, Raghu, and Peter Karnøe. 2001. Path creation as a process of mindful deviation. In Path dependence and creation, ed. Raghu Garud, and Peter Karnøe, 1-38. Mahwah, NJ: Erlbaum.

Garud, Raghu, Arun Kumaraswamy, and Peter Karnøe. 2010. Path dependence or path creation? Journal of Management Studies 47(4): 760-774.

Geiger, Daniel, and Elena Antonacopoulou. 2009. Narratives and organizational dynamics: Exploring blind spots and organizational inertia. Journal of Applied Behavioral Science 45(3): 411-436.

Gilbert, Clark G. 2005. Unbundling the structure of inertia: Resource versus routine rigidity. Academy of Management Journal 48(5): 741-763.

Gilbert, Clark G. 2006. Change in the presence of residual fit: Can competing frames coexist? Organization Science 17(1): 150-167.

Gilbert, Clark G., and Joseph L. Bower. 2002. Disruptive change: When trying harder is part of the problem. Harvard Business Review 80(5): 94-101.

Glaser, Barney, and Anselm Strauss. 1967. The discovery of grounded theory: Strategies of qualitative research. London: Wiedenfeld and Nicholson.

Greve, Henrich R., and Marc-David L. Seidel. 2014. The thin red line between success and failure: Path dependence in the diffusion of innovative production technologies. Strategic Management Journal 36(4): 475-496.

Gruber, Marc. 2010. Exploring the origins of organizational paths: Empirical evidence from newly founded firms. Journal of Management 36(5): 1143-1167.

Hill, Charles W.L., and Frank T. Rothaermel. 2003. The performance of incumbent firms in the face of radical technological change. Academy of Management Review 28(2): 257-274.

Huff, Ann S. 1982. Industry influences on strategy reformulation. Strategic Management Journal 3(2): 119-131.

Hutzschenreuter, Thomas, and Ingo Kleindienst. 2013. (How) Does discretion change over time? A contribution toward a dynamic view of managerial discretion. Scandinavian Journal of Management 29(3): 264-281. 
Hutzschenreuter, Thomas, Torben Pedersen, and Henk W. Volberda. 2007. The role of path dependency and managerial intentionality: A perspective on international business research. Journal of International Business Studies 38(7): 1055-1068.

Isabella, Lynn A. 1990. Evolving interpretations as a change unfolds: How managers construe key organizational events. Academy of Management Journal 33(1): 7-41.

Kaplan, Sarah. 2008. Cognition, capabilities, and incentives: Assessing firm response to the fiber-optic revolution. Academy of Management Journal 51(4): 672-695.

Kaplan, Sarah, and Rebecca Henderson. 2005. Inertia and incentives: Bridging organizational economics and organizational theory. Organization Science 16(5): 509-521.

Klag, Malvina, and Ann Langley. 2013. Approaching the conceptual leap in qualitative research. International Journal of Management Reviews 15(2): 149-166.

Klein, Katherine J., Fred Danserau, and Rosalie J. Hall. 1994. Level issues in theory development, data collection, and analysis. Academy of Management Review 19(2): 195-229.

Koch, Jochen. 2008. Strategic paths and media management: A path dependency analysis of the German newspaper branch of high quality journalism. Schmalenbach Business Review 60(1): 51-74.

Koch, Jochen. 2011. Inscribed strategies: Exploring the organizational nature of strategic lock-in. Organization Studies 32(3): 337-363.

Koch, Jochen, Martin Eisend, and Arne Petermann. 2009. Path dependence in decision-making processes: Exploring the impact of complexity under increasing returns. Business Research 2(1): 67-84.

Kunow, Kristian, Martin Gersch, and Jochen Koch. 2013. Temporary incompetence as a path-breaking strategy: Two major record companies' efforts to escape their competence lock-in. Jahrbuch Strategisches Kompetenz Management 6: 9-33.

Lampel, Joseph, and Jamal Shamsie. 2003. Capabilities in motion: New organizational forms and the reshaping of the Hollywood movie industry. Journal of Management Studies 40(8): 2189-2210.

Langley, Ann, and Chahrazad Abdallah. 2011. Templates and turns in qualitative studies of strategy and management. Research Methodology in Strategy and Management 6: 201-235.

Langley, Ann, Clive Smallman, Hari Tsoukas, and Andrew H. Van de Ven. 2013. Process studies of change in organization and management: Unveiling temporality, activity, and flow. Academy of Management Journal 56(1): 1-13.

Leonard-Barton, Dorothy. 1992. Core capabilities and core rigidities: A paradox in managing new product development. Strategic Management Journal 13(S1): 111-125.

Levinthal, Daniel A., and James G. March. 1993. The myopia of learning. Strategic Management Journal 14(S2): 95-112.

Lincoln, Yvonna S., and Egon G. Guba. 1985. Naturalistic inquiry. Newbury Park, CA: Sage.

MacKay, R. Bradley, and Robert Chia. 2013. Choice, chance, and unintended consequences in strategic change: A process understanding of the rise and fall of NorthCo Automotive. Academy of Management Journal 56(1): 208-230.

Mahoney, James. 2000. Path dependence in historical sociology. Theory and Society 29(4): 507-548.

Maielli, Giuliano. 2015. Explaining organizational paths through the concept of hegemony: Evidence from the Italian car industry. Organization Studies 36(4): 491-511.

March, James G. 1991. Exploration and exploitation in organizational learning. Organization Science 2(1): 71-87.

McKinley, William, Scott Latham, and Michael Braun. 2014. Organizational decline and innovation: Turnarounds and downward spirals. Academy of Management Review 39(1): 88-110.

Meyer, Uli, and Cornelius Schubert. 2007. Integrating path dependency and path creation in a general understanding of path constitution. The role of agency and institutions in the stabilisation of technological innovations. Science, Technology and Innovation Studies 3: 23-44.

Miles, Matthew B., and A.Michael Huberman. 1994. Qualitative data analysis: An expanded source book, 2nd ed. Thousand Oaks, CA: Sage.

Miller, Danny. 1993. The architecture of simplicity. Academy of Management Review 18(1): 116-138.

Miller, Danny. 1994. What happens after success: The perils of excellence. Journal of Management Studies 31(3): 325-358.

Miller, Danny, and Ming-Jer Chen. 1994. Sources and consequences of competitive inertia: A study of the U.S. airline industry. Administrative Science Quarterly 39(1): 1-23.

Mishina, Yuri, Emily S. Block, and Michael J. Mannor. 2012. The path dependence of organizational reputation: How social judgment influences assessments of capability and character. Strategic Management Journal 33(5): 459-477. 
O’Reilly, Charles A., and Michael L. Tushman. 2013. Organizational ambidexterity: Past, present, and future. Academy of Management Perspectives 27(4): 327-338.

Pearson, Christine M., and Judith A. Clair. 1998. Reframing crisis management. Academy of Management Review 23(1): 59-76.

Pierson, Paul. 2000. Increasing returns, path dependence, and the study of politics. American Political Science Review 94(2): 251-267.

Porac, Joseph F., and Howard Thomas. 1989. Managerial thinking in business environments. Journal of Management Studies 26(4): 323-324.

Porac, Joseph F., Howard Thomas, and Charles Baden-Fuller. 1989. Competitive groups as cognitive communities: The case of Scottish knitwear manufacturers. Journal of Management Studies 26(4): 397-416.

Porter, Michael E. 1980. Competitive strategy. New York: Free Press.

Rindova, Violina P., Ian O. Williamson, Antoaneta P. Petkova, and Joy M. Sever. 2005. Being good or being known: An empirical examination of the dimensions, antecedents, and consequences of organizational reputation. Academy of Management Journal 48(6): 1033-1049.

Rosenbloom, Richard S. 2000. Leadership, capabilities, and technological change: The transformation of NCR in the electronic era. Strategic Management Journal 21(10-11): 1083-1103.

Rothmann, Wasko. 2013. Wahrnehmung des strategischen Handlungsspielraumes. Die verlegerische Entwicklung der deutschen Qualitätstageszeitungen seit 2001. Wiesbaden: Springer VS.

Rothmann, Wasko, and Jochen Koch. 2014. Creativity in strategic lock-ins: The newspaper industry and the digital revolution. Technological Forecasting and Social Change 83(3): 66-83.

Sambamurthy, Vallabh, Anandhi Bharadwaj, and Varun Grover. 2003. Shaping agility through digital options: Reconceptualizing the role of information technology in contemporary firms. MIS Quarterly 27(2): 237-263.

Schmidt, Thomas, and Timo Braun. When cospecialization leads to rigidity: Path dependence in successful strategic networks. Schmalenbach Business Review (forthcoming).

Schmidt, Jens, and Thomas Keil. 2013. What makes a resource valuable? Identifying the drivers of firmidiosyncratic resource value. Academy of Management Review 38(2): 206-228.

Schreyögg, Georg, and Martina Kliesch-Eberl. 2007. How dynamic can organizational capabilities be? Towards a dual-process model of capability dynamization. Strategic Management Journal 28(9): 913-933.

Schreyögg, Georg, Jörg Sydow, and Philip Holtmann. 2011. How history matters in organisations: The case of path dependence. Management and Organizational History 6(1): 81-100.

Schultz, Majken, and Thor Hernes. 2013. A temporal perspective on organizational identity. Organization Science 24(1): 1-21.

Shapiro, Carl, and Hal R. Varian. 1999. Information rules: A strategic guide to the network economy. Boston: Harvard Business School Press.

Siggelkow, Nicolai. 2007. Persuasion with case studies. Academy of Management Journal 50(1): 20-24.

Spender, J.-C. 1989. Industry recipes: An enquiry into the nature and sources of managerial judgment. Oxford, UK: Blackwell.

Strauss, Anselm L. 1987. Qualitative analysis for social scientists. Cambridge, MA: Cambridge University Press.

Sull, Donald N. 1999. The dynamics of standing still: Firestone Tire \& Rubber and the radial revolution. Business History Review 73(3): 430-464.

Sydow, Jörg, Georg Schreyögg, and Jochen Koch. 2009. Organizational path dependence: Opening the black box. Academy of Management Review 34(4): 689-709.

Sydow, Jörg, Arnold Windeler, Gordon Müller-Seitz, and Knut Lange. 2012a. Path constitution analysis: A methodology for understanding path dependence and path creation. Business Research 5(2): 155-176.

Sydow, Jörg, Arnold Windeler, Cornelius Schubert, and Guido Möllering. 2012b. Organizing R\&D consortia for path creation and extension: The case of semiconductor manufacturing technologies. Organization Studies 33(7): 907-936.

Tripsas, Mary. 1997. Unraveling the process of creative destruction: Complementary assets and incumbent survival in the typesetter industry. Strategic Management Journal 18(S1): 119-142.

Tripsas, Mary. 2009. Technology, identity, and inertia through the lens of "The Digital Photography Company". Organization Science 20(2): 95-119.

Tripsas, Mary, and Giovanni Gavetti. 2000. Capabilities, cognition, and inertia: Evidence from digital imaging. Strategic Management Journal 21(10/11): 1147-1161. 
Tushman, Michael L., and Philip Anderson. 1986. Technological discontinuities and organizational environments. Administrative Science Quarterly 31(3): 439-465.

Van Maanen, John. 1979. The fact of fiction in organizational ethnography. Administrative Science Quarterly 24(4): 539-550.

Vergne, Jean-Philippe, and Rodolphe Durand. 2010. The missing link between the theory and empirics of path dependence: Conceptual clarification, testability issue, and methodological implications. Journal of Management Studies 47(4): 736-759.

Vergne, Jean-Philippe, and Rodolphe Durand. 2011. The path of most persistence: An evolutionary perspective on path dependence and dynamic capabilities. Organization Studies 32(3): 365-382.

Weick, Karl E. 1979. The social psychology of organizing, 2nd ed. Reading, MA: Addison-Wesley.

Yin, Robert K. 2014. Case study research: Design and methods, 5th ed. Los Angeles: Sage. 